\title{
UV-B ışın uygulamalarının domates, hıyar ve patlıcan fidelerinde fide gelişimi ve kalitesi üzerine etkileri
}

\section{The effects of UV-B irradiation on development and quality of tomato, cucumber and eggplant seedlings}

\author{
Serkan CANBAY ${ }^{1}\left(\mathbb{D}\right.$, Ersin POLAT $^{2}$ (D) \\ ${ }^{1}$ Antalya Gıda Kontrol Laboratuvar Müdürlüğü, 07260, Kepez/Antalya \\ ${ }^{2}$ Akdeniz Üniversitesi, Ziraat Fakültesi, Bahçe Bitkileri Bölümü, 07070, Antalya \\ Sorumlu yazar (Corresponding author): S. Canbay, e-posta (e-mail): serkancnby@gmail.com \\ Yazar(lar) e-posta (Author e-mail): polat@akdeniz.edu.tr
}

\section{MAKALE BİLGİSİ}

Alınış tarihi 15 Kasım 2018

Düzeltilme tarihi 02 Ocak 2019

Kabul tarihi 22 Ocak 2019

\section{Anahtar Kelimeler:}

Cucumis sativus $\mathrm{L}$.

Solanum lycopersicum L.

Solanum melongena $\mathrm{L}$.

UV-B

\begin{abstract}
öz
Bu çalışmada, UV-B ışın uygulamalarının domates, hıyar ve patlıcan fidelerinde fide gelişimi ve kalitesi üzerine etkileri araştırılmıştır. Bu amaçla domates (Solanum lycopersicum L. cv. Alsancak-RN $\mathrm{F}_{1}$ ), hıyar (Cucumis sativus $\mathrm{L}$. cv. Çakır $\mathrm{F}_{1}$ ) ve patlıcan (Solanum melongena $\mathrm{L}$. cv. Anamur $\left.F_{1}\right)$ fideleri kontrol $\left(0 \mathrm{~kJ} \mathrm{~m}^{-2}\right.$ gün $\left.^{-1}\right), 10.8 \mathrm{~kJ} \mathrm{~m}^{-2}$ gün$^{-1}$ (düşük doz) ve 16.2 $\mathrm{kJ} \mathrm{m}^{-2}$ gün $^{-1}$ (yüksek doz) UV-B ışın uygulamasına ilk gerçek yapraklı oldukları dönemden itibaren 10 gün (sırasıyla $76.5 \mathrm{dk}$ gün $^{-1}$ ve $114.75 \mathrm{dk}$ gün $^{-1}$ ) süre ile tabi tutulmuşlardır Araştırmada fide boyu, yaprak sayısı, kök boğazı çapı, kök uzunluğu, kök ve üst aksam yaş ve kuru ağırlıkları, yaprak alanı, yaprakta klorofil miktarı ve yaprak rengi belirlenmiștir. Domates fide yapraklarındaki klorofil miktarı, düsük doz UV-B ıșın uygulamasında artarken yüksek doz UV-B uygulamasında azalmıştır. Yüksek doz UV-B ışın uygulamasının, fide köklerinde kuru madde miktarını artırdığı belirlenmiştir. Hıyar fide yapraklarındaki klorofil miktarı, düşük doz UV-B uygulamasında artmıştır. Fidelerde yaprak sayısı ve yaprak alanı, düşük doz UV-B uygulamasında artarken, yüksek doz UV-B uygulamasında ise azalmıştır. Kök boğazı çapı, kök uzunluğu ve üst aksamdaki kuru madde miktarının yüksek doz UV-B uygulamasında azaldığı saptanmıştır. Düşük doz UV-B uygulanan patlıcan fidelerinde yaprak rengi Chroma $\left(C^{*}\right)$ değerinin azaldığı tespit edilmiştir. UV-B uygulamalarının patlıcan fidelerinde yaprak rengi $L^{*}$ değeri, kök boğazı çapı ve yaprak alanını azaltıcı etki yaptığı belirlenmiştir. UV-B ışın uygulamalarının türe ve doz miktarına bağlı olarak fidelerin gelişimi ve morfolojik yapısı üzerine etki ettiği belirlenmiştir.
\end{abstract}

\section{ARTICLE INFO}

Received 15 November 2018

Received in revised form 02 January 2019

Accepted 22 January 2019

\section{Keywords:}

Cucumis sativus L.

Solanum lycopersicum $\mathrm{L}$

Solanum melongena $\mathrm{L}$.

UV-B

\section{ABSTRACT}

The aim of the study was to investigate the effects of UV-B irradiation on development and quality of tomato, cucumber and eggplant seedlings. Tomato (Solanum lycopersicum L. cv. Alsancak-RN), cucumber (Cucumis sativus L. cv) and eggplant (Solanum melongena L. cv.) seedlings were subjected to UV-B irradiation $0 \mathrm{~kJ} \mathrm{~m}^{-2}$ day $^{-1}, 10.8 \mathrm{~kJ} \mathrm{~m}^{-2} \mathrm{day}^{-1}$ and 16.2 $\mathrm{kJ} \mathrm{m}^{-2} \mathrm{day}^{-1}$ for 10 days $\left(76.5 \mathrm{~min}_{\text {day }}{ }^{-1}-114.75 \mathrm{~min} \mathrm{day}^{-1}\right.$ ) when they reached to the first true leaves stage. In this research, seedling length, number of leaves, root coolar diameter, root length, root and upper age and dry weights, leaf area, chlorophyll content in leaf and color measurement values were determined. The content of chlorophyll in the tomato seedling was increased in low dose UV-B application and decreased at $16.2 \mathrm{~kJ} \mathrm{~m}^{-2}$ day $^{-1} \mathrm{UV}-\mathrm{B}$ irradiation. It was determined that high dose UV-B irradiation caused an increase in the amount of dry matter in the root. Chlorophyll amount in cucumber seedlings increased in low dose UV-B application. Leaf number and leaf area increased in low dose UV-B application, decreased in high dose UV-B application. Decrease was observed on the root coolar diameter, root length, upper plant part dry matter with UV-B irradiations. Low dose UV-B applied eggplant seedlings decreased choroma value. It has been determined that UV-B applications reduce $\mathrm{L}^{*}$ color value, root collar diameter and leaf area in eggplant seedlings. UV-B irradiation caused plant development and morphological changes on the seedling depending on the dose and plant species. 


\section{Giriş}

Güneşten yayılan enerji, fotosentez yoluyla dünya üzerindeki hayatın hemen hemen tamamının var olmasını sağlayan en önemli kaynaktır. Dünyaya güneşten gelen 1şınlardan dalga boyları $4000-3150 \quad \mathrm{~A}^{\mathrm{o}}$ arasında olan "Ultraviyole A" 1şınları dalga boyları 3150-2800 $\mathrm{A}^{\circ}$ arasında olan "Ultraviyole B" 1şınları, dalga boyları $2800 \mathrm{~A}^{\mathrm{o}^{\prime}}$ dan küçük olan "Ultraviyole $\mathrm{C}$ " 1şınları olarak adlandırılırlar. Yeryüzüne gelen toplam 1şıkların yaklaşı \% 39'u dalga boyları 4000-7000 $\mathrm{A}^{\circ}$ arasında olan ve gözle görülebilen, \% 60 kadarı dalga boyu $7000 \mathrm{~A}^{\circ}$ dan büyük olan ve \% 1 kadarı da dalga boyu 4000 $\mathrm{A}^{\circ}$ dan küçük olan ışınlardan oluşmaktadır. Ozon tabakası UV radyasyonu için koruyucu bir bariyerdir. Ozon tabakasındaki incelme, yeryüzüne ulaşan UV-B radyasyon düzeyinde artışa yol açmakta ve bu da biyolojik ve kimyasal süreçleri olumsuz yönde etkilemektedir. Çünkü güneşten kaynaklanan UV-B ya da yakıcı UV 1şınları, atmosferin toplam ozon içeriğindeki değişimlere karşı çok hassastır. Ozondaki her \% 1'lik azalma, biyosfere ulaşan UV-B 1şınında \% 1.3-1.8'lik artışa sebep olmaktadır (Anderson ve ark. 1991; McFarland ve Kaye 1992). Bitkiler yapılarındaki farklılıklar nedeniyle ozona dayanıklılık açısından değişkenlik gösterirler. Değişkenlik; bitkinin tür, alt tür ve varyete özelliklerine bağlı olarak değişir (Fedina ve ark. 2010).

Çevre şartlarının bir canlının normal gelişme ve büyümesini olumsuz yönde etkileyecek kadar değişmesi halinde canlılarda oluşan durum stres olarak tanımlanmaktadır. Canlı varlıklar yaşamları boyunca çok sayıda stres faktörü ile karşılaşmaktadır. Fidelerde aşırı boylanmanın önlenmesi, çevre koşullarının çok iyi kontrol edilmesi veya büyümeyi geciktirici bazı kimyasal maddelerin kullanılması ile mümkündür. Süs bitkileri yetiştiriciliğinde yaygın olarak kullanılan bu kimyasallar son yıllarda sayıları hızla artan, ticari sebze fidesi yetiştiriciliği yapan kuruluşlar tarafından da kullanılmaktadır. Ancak, çoğunlukla genç fide döneminde yaprak yüzeyine uygulanan bu maddelerin dozları iyi ayarlanmadığında, fidede kloroza, daha sonraki büyüme ve gelişme döneminde uzun süreli duraklamaya, ürün almada gecikmeye sebep olurken aynı zamanda çevre kirliliğine de yol açmaktadır. (Uslu ve Özgür 2002).

UV-B radyasyonunun eko-fizyolojik rolünü anlamak için UV-B'nin oluşturduğu hasar, tamir veya koruma gibi fizyolojik süreçlerin mekanizmalarının anlaşılması önemlidir (Zlatev ve ark. 2012). Fide işletmelerinde pişkin fide üretimi bitki gelişim düzenleyiciler ya da iklimsel faktörler (sıcaklık, 1şık, nem vs.), sulama ve gübreleme dengelerini değiştirmek gibi çeşitli teknikler kullanarak yapılmaktadır. Bu çalışma domates, hıyar ve patlıcan fidelerine uygulanan farklı dozlardaki UV-B ışın uygulamalarının fidelerde büyüme ve gelişmeye olan etkisini belirlenmesi ve fide yetiştiriciliğinde adaptasyon ve pişkinleştirme işlemlerine katkı sağlaması amacıyla yapılmışıtır.

\section{Materyal ve Yöntem}

Bu çalışma, Akdeniz Üniversitesi Ziraat Fakültesi Bahçe Bitkileri Bölümü cam serasında yürütülmüştür. Araştırmada, deneme materyali olarak, Antalya il sınırları içerisindeki ticari bir fide üreticisinden sağlanan domates (Solanum lycopersicum L. cv. Alsancak-RN F 1 ), hıyar (Cucumis sativus L. cv. Çakır F F $_{1}$ ve patlican (Solanum melongena L. cv. Anamur $\mathrm{F}_{1}$ ) fideleri kullanılmıştır.

Fideler, kontrol dahil olmak üzere 3 gruba ayrılmış ve ilk iki grup, stratosferik ozon tabakasındaki \%20 ve \% 25'lik incelmeye karşıllk gelebilecek doz için sırasıyla 4.25 ve 5.31 $\mathrm{kJ} \mathrm{m}^{-2}$ gün $^{-1}$ olarak uygulayan Yuan ve ark. (1998)'nın belirttiği değerler referans alınmıştır. Buna göre çalışmada etkisi görülmek istenen uygulama dozları $10.8 \mathrm{~kJ} \mathrm{~m}^{-2}$ gün-1 (düşük doz) ve $16.2 \mathrm{~kJ} \mathrm{~m}^{-2}$ gün $^{-1}$ (yüksek doz) olarak belirlenmiştir. Üçüncü grup fidelere ise UV-B ışını uygulanmamış, bu grup kontrol olarak denemede yer almıştır. Sistem, lambaların bitkiler üzerinde farklı yüksekliklere ayarlanmasına imkan verecek şekilde dizayn edilmiştir. UV-B 1şın uygulamaları 311 $\mathrm{nm}$ dalga boyunda 1şın yayan ve $25 \mathrm{~mm}$ çapında dar band UV-B lambalar (Philips TL 100W/01 UV-B) ile gerçekleştirilmiştir. Belirtilen dozların ayarlaması, Watt $\mathrm{x}$ saniye $=$ Joule formülünden yararlanılarak hesaplanmış ve uygulamaya konulmuştur. İlk uygulamada doz ayarlaması dijital radyometrenin 0 değeri ölçtüğü akşam saatinde, UV-B lambası açılmış ve sensör lambadan $25 \mathrm{~cm}$ altta olacak şekilde tutularak yaklaşık 10 farklı noktadan ölçümler yapılmıştır. Radyometrede okunan ortalama $240 \mu \mathrm{W} \mathrm{cm}{ }^{-2}\left(2.40 \mathrm{~W} \mathrm{~m}^{-2}\right)$ değeri formülde yerine konulduğunda lambalar; $10.8 \mathrm{~kJ} \mathrm{~m}^{-2}$ gün$^{-1}$ için $76.5 \mathrm{dk}$, $16.2 \mathrm{~kJ} \mathrm{~m}^{-2}$ gün $^{-1}$ için $114.75 \mathrm{dk}$ çalıştırılarak uygulama yapılacak dozlar hesaplanmıştır. Fidelere ilk gerçek yapraklı oldukları dönemde bitki tepe noktasının $25 \mathrm{~cm}$ üstüne lambalar yerleştirilerek 10 gün süre ile UV-B 1şın uygulaması yapılmıştır. Uygulama süresi boyunca hastalık ve zararlılara karşı herhangi bir bitki koruma ürünü kullanılmamış ve gübreleme yapılmamıştır.

UV-B ışın uygulamasıyla birlikte araştırma serasının hem iç hem de diş koşullardaki anlık 1şık miktarı Lux metre (Light Meter Lx-1108) cihazı ile belirlenmiştir. Günlük aynı saatte anlık 1şık ölçümü yapılarak değerler kayıt altına alınmıştır (Şekil 1).

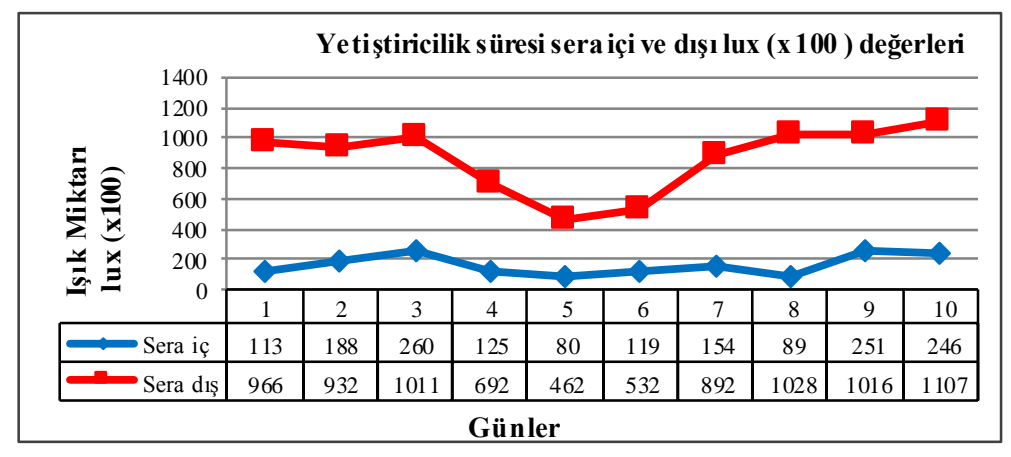

Şekil 1. Uygulamaların yapıldığı 13-22/05/2017 tarihlerinde cam serada iç ve dış ışıklanma değerleri.

Figure 1. Interior and exterior lighting values in glass house between 13-22 /05/2017. 
Çalışmada fide boyu, kök boğazı çapı, kök uzunluğu, yaprak sayıs1, yaprak alanı, yaprakta klorofil miktarı, yaprak rengi, kök ve toprak üstü aksamda kuru madde ve protein miktarı belirlenmiştir.

Fide boyu ve kök uzunluğu cetvel ile kök boğazı çapı ise dijital kumpas ile ölçülmüştür. Yaprak alanı CI-202 marka lazer yaprak alan ölçer cihazı yardımı ile ölçülüp, ortalama alanları $\mathrm{cm}^{2}$ olarak belirtilmiştir. Klorofil miktarı Spad-502 Plus klorofilmetre cihazı ile tespit edilmiştir. Yaprak rengi; 3 ayrı noktada kromametre (CR 400, Minolta, Konica, Tokyo, Japonya) ile $L^{*}$, Chroma $\left(C^{*}\right)$ ve Hue $\left(H^{9}\right)$ açısı değerleri ölçülmüştür.

Kuru madde miktarı belirlenirken örnekler $70^{\circ} \mathrm{C}$ 'de sabit ağırlığa ulaşıncaya kadar vakumlu etüvde kurutulduktan sonra desikatörde soğutulup, $0.0001 \mathrm{~g}$ 'a duyarlı dijital bir terazi ile tartılarak gram cinsinden hesaplanmıştır (TS1129/ISO 1026 1998). Protein analizi Leco FP-528 cihazında AOAC 992.23 metoduna göre yapılmıştır (Association of Official Analytical Chemists 1992).

Araştırma 3 tekerrürlü ve her tekerrürde 15 fide olacak şekilde tesadüf parselleri deneme desenine göre kurulmuştur. İstatistiksel analizlerde ortalamaların karşıllaştırılmasında LSD Çoklu Karşılaştırma Testi $(P \leq 0.01,0.05)$ kullanılmıştır.

\section{Bulgular ve Tartışma}

3.1. Fide boyu, kök boğazı çapı, kök uzunluğu, yaprak sayısı ve yaprak alanı

Farklı dozlarda UV-B uygulamalarının domates, hiyar ve patlıcan fidelerinin fide boyu üzerine etkisi istatistiksel olarak önemsiz bulunmuştur. UV-B uygulamaları domates fidelerinde kök boğazı çapını artırırken, hıyar ve patlıcan fidelerinin kök boğazı çapında azalmaya neden olmuştur (Çizelge 1, 2 ve 3).

Kontrol grubu ile $16.2 \mathrm{~kJ} \mathrm{~m}^{-2}$ gün $^{-1}$ (yüksek doz) UV-B ışıı uygulaması yapılan domates fidelerinde kök uzunluğu istatiksel olarak benzerlik gösterirken, $10.8 \mathrm{~kJ} \mathrm{~m}^{-2}$ gün ${ }^{-1}$ (düşük doz) UVB uygulaması yapılan fidelerde kök gelişiminin baskılandığ görülmüştür. Hiyar fidelerinde ise düşük doz UV-B uygulamasının yüksek doz UV-B uygulamasına göre kök uzamasını daha fazla baskıladığ belirlenmiştir (Çizelge 1 ve 2).

Düşük doz UV-B uygulaması domates fidelerinin yaprak sayısında (2.83 adet bitki $\left.{ }^{-1}\right)$ azalmaya neden olurken yüksek doz yaprak sayısında (3.44 adet bitki $\left.{ }^{-1}\right)$ artışa sebep olmuştur. Buna karşın, hıyar fidelerinde $10.8 \mathrm{~kJ} \mathrm{~m}^{-2}$ gün ${ }^{-1}$ UV-B 1 şın uygulaması yapılan fidelerde yaprak sayısının $\left(2.75\right.$ adet bitki $\left.{ }^{-1}\right)$ arttığı, $16.2 \mathrm{~kJ} \mathrm{~m}^{-2}$ gün$^{-1}$ UV-B 1şın uygulaması yapılan fidelerde ise yaprak sayısının (2.50 adet bitki $\left.{ }^{-1}\right)$ azaldığ 1 tespit edilmiştir. Kontrol grubu fidelerin yaprak sayısı 2.69 adet bitki $^{-1}$ ile 10.8 ve $16.2 \mathrm{~kJ} \mathrm{~m}^{-2}$ gün$^{-1} \mathrm{UV}$-B uygulaması yapılan fidelerin arasında bir değer alarak UV-B uygulamaları ile benzerlik gösterdiği tespit edilmiştir (Çizelge 1 ve 2).

$16.2 \mathrm{~kJ} \mathrm{~m}^{-2}$ gün $^{-1}$ UV-B 1 şın uygulaması yapılan hıyar fidelerinde yaprak alanının $\left(35.84 \mathrm{~cm}^{2}\right)$ kontrol grubuna (39.59 $\mathrm{cm}^{2}$ ) göre azaldığ ${ }_{1}, 10.8 \mathrm{~kJ} \mathrm{~m}^{-2}$ gün $^{-1}$ UV-B 1şın uygulaması yapılan hıyar fidelerinde ise yaprak alanının $\left(45.37 \mathrm{~cm}^{2}\right)$ arttığ belirlenmiştir. Patlıcan fidelerinde UV-B ışın uygulamalarına bağlı olarak yaprak alanı miktarında azalma meydana geldiği görülmüştür. $10.8 \mathrm{~kJ} \mathrm{~m}^{-2}$ gün $^{-1} \mathrm{UV}-\mathrm{B}$ uygulaması yapılan fidelerde $35.96 \mathrm{~cm}^{2}, 16.2 \mathrm{~kJ} \mathrm{~m}^{-2}$ gün$^{-1} \mathrm{UV}-\mathrm{B}$ uygulamas1 yapılan fidelerde $37.54 \mathrm{~cm}^{2}$ yaprak alanı saptanmıştır. Kontrol grubu fidelerde ise $46.09 \mathrm{~cm}^{2}$ ile en fazla yaprak alanı tespit edilmiştir (Çizelge 2 ve 3).

Çizelge 1. Farklı UV-B doz uygulamaların domates fidelerinde fide boyu, kök boğazı çapı, kök uzunluğu, yaprak sayısı ve yaprak alanına olan etkisi.

Table 1. The effect of different UV-B dose applications on seedling height, root collar diameter, root length, number of leaves and leaf area in tomato seedlings.

\begin{tabular}{lccccc}
\hline Uygulama Dozları & Fide boyu $(\mathrm{cm})$ & Kök boğazı çapı $(\mathrm{mm})$ & Kök uzunluğu $(\mathrm{cm})$ & Yaprak sayısı (adet bitki $\left.{ }^{-1}\right)$ & Yaprak alanı $\left(\mathrm{cm}^{2}\right)$ \\
\hline Kontrol & 10.01 & $4.06 \mathrm{~b}$ & $11.51 \mathrm{a}$ & $3.06 \mathrm{~b}$ & 25.70 \\
$10.8\left(\mathrm{~kJ} \mathrm{~m}^{-2}\right.$ gün $\left.^{-1}\right)$ & 10.87 & $4.56 \mathrm{a}$ & $8.48 \mathrm{~b}$ & $2.83 \mathrm{c}$ & 27.37 \\
$16.2\left(\mathrm{~kJ} \mathrm{~m}^{-2}\right.$ gün $\left.^{-1}\right)$ & 10.83 & $4.61 \mathrm{a}$ & $11.91 \mathrm{a}$ & $3.44 \mathrm{a}$ & 28.87 \\
\hline
\end{tabular}

LSD $\%_{5}$ (fide boyu $)=$ Ö.D., LSD $\% 5($ kök boğazı çapı $)=0.430, \mathrm{LSD} \% 1$ (kök uzunluğu $)=1.106, \mathrm{LSD} \% 1$ (yaprak sayısı) $)=0.187, \mathrm{LSD} \% 5($ yaprak alanı $)=$ Ö.D.

Çizelge 2. Farklı UV-B doz uygulamaların hıyar fidelerinde fide boyu, kök boğazı çapı, kök uzunluğu, yaprak sayısı ve yaprak alanına olan etkisi.

Table 2. The effect of different UV-B dose applications on seedling height, root collar diameter, root length, number of leaves and leaf area in cucumber seedlings.

\begin{tabular}{lccccc}
\hline Uygulama Dozları & Fide boyu $(\mathrm{cm})$ & Kök boğazı çapı $(\mathrm{mm})$ & Kök uzunluğu $(\mathrm{cm})$ & Yaprak sayısı (adet bitki $\left.{ }^{-1}\right)$ & Yaprak alanı $\left(\mathrm{cm}^{2}\right)$ \\
\hline Kontrol & 11.74 & $6.83 \mathrm{a}$ & $10.82 \mathrm{a}$ & $2.69 \mathrm{ab}$ & $39.59 \mathrm{~b}$ \\
$10.8\left(\mathrm{~kJ} \mathrm{~m}^{-2}\right.$ gün $\left.^{-1}\right)$ & 10.86 & $6.00 \mathrm{~b}$ & $9.86 \mathrm{c}$ & $2.75 \mathrm{a}$ & $45.37 \mathrm{a}$ \\
$16.2\left(\mathrm{~kJ} \mathrm{~m}^{-2}\right.$ gün $\left.^{-1}\right)$ & 11.81 & $5.78 \mathrm{~b}$ & $10.35 \mathrm{~b}$ & $2.50 \mathrm{~b}$ & $35.84 \mathrm{c}$ \\
\hline
\end{tabular}

LSD $\% 5$ (fide boyu $)=$ Ö.D., LSD $\% 5($ kök boğazı çap 1$)=0.558$, LSD $\% 5($ kök uzunluğu $)=0.339$, LSD $\% 5($ yaprak say1s1 $)=0.195$, LSD $\% 1($ yaprak alanı $)=2.830$

Çizelge 3. Farklı UV-B doz uygulamaların patlıcan fidelerinde fide boyu, kök boğazı çapı, kök uzunluğu, yaprak sayısı ve yaprak alanına olan etkisi.

Table 3. The effect of different UV-B dose applications on seedling height, root collar diameter, root length, number of leaves and leaf area in eggplant seedlings.

\begin{tabular}{lcccc}
\hline Uygulama Dozları & Fide boyu $(\mathrm{cm})$ & Kök boğazı çapı $(\mathrm{mm})$ & Kök uzunluğu $(\mathrm{cm})$ & Yaprak sayısı $\left(\right.$ adet bitki $\left.{ }^{-1}\right)$ \\
\hline Kontrol & 12.87 & $4.78 \mathrm{a}$ & 8.02 & 3.44 \\
$10.8\left(\mathrm{~kJ} \mathrm{~m}^{-2}\right.$ gün $\left.^{-1}\right)$ & 12.39 & $3.94 \mathrm{~b}$ & 7.93 & 2.94 \\
$16.2\left(\mathrm{~kJ} \mathrm{~m}^{-2}\right.$ gün $\left.^{-1}\right)$ & 13.13 & $4.11 \mathrm{~b}$ & 7.79 & $35.96 \mathrm{~b}$ \\
\hline
\end{tabular}

LSD $\% 1$ (fide boyu)= Ö.D., LSD \% 1 (kök boğazı çap1)= 0.655, LSD \% 1 (kök uzunluğu)= Ö.D., LSD \% 1 (yaprak sayı1) $=$ Ö.D., LSD \% 1 (yaprak alan1)= 5.302. 
Del Corso ve Lercari (1997) serada yetiştirilen domates fidelerinde bitki boyunu kontrol etmek ve fidelerin diş ortama alıştırılmalarını sağlamak amacıyla yaptıkları UV-B uygulamaları sonucunda kullanılan doza bağlı olmak üzere UV radyasyon uygulamasının yaprak alanını \%65 oranında azalttığını saptamışlardır. Yürütülen çalışmada ise, hıyar fidelerinde yüksek doz UV-B uygulaması ile, patlıcan fidelerinde UV-B'nin her iki doz uygulaması fide yaprak alanında azalmaya neden olmuştur. Sonuçlar yukarıdaki araştırmacıların sonuçları ile uyum göstermektedir.

Shaukat ve ark. (2013) UV-B 1şın uygulamalarının, siyah mercimeğin (Vigna mungo L.) çimlenmesi, fide büyümesi üzerine yaptıkları çalışma sonucunda UV-B ışının artmasıyla fidelerdeki kök ve sürgün gelişiminin önemli ölçüde azaldığını belirlemişlerdir. Çalışmamızda hıyar fidelerinde elde edilen sonuçlar araştırıcıların çalışması ile paralellik gösterirken, domates fidelerinde yüksek doz $\left(16.2 \mathrm{~kJ} \mathrm{~m}^{-2}\right.$ gün $\left.^{-1}\right) \quad \mathrm{UV}-\mathrm{B}$ uygulamasının kök uzunluğunu üzerine bir etkisi olmadığ1, 10.8 $\mathrm{kJ} \mathrm{m}^{-2}$ gün $^{-1}$ UV-B 1şın uygulamasının ise kök uzunluğunda azalmaya neden olduğu tespit edilmiştir.

\subsection{Klorofil miktarl, yaprak rengi ( $L^{*}, C^{*} v e H^{o}$ açısı değerleri)}

Domates ve hıyar fidelerine düşük doz UV-B uygulamalarının klorofil miktarını artırdığı belirlenmiştir. Yüksek doz UV-B uygulaması yapılan domates fidelerinde klorofil miktarı azalırken, kontrol grubu domates fidelerinin klorofil miktarı 48.95 SPAD ile UV-B uygulamaları yapılan fidelere istatiksel olarak benzerlik gösterdiği belirlenmiştir. Kontrol grubu ile yüksek doz UV-B uygulaması yapılan hiyar fidelerinin klorofil miktarı ise istatiksel olarak benzerlik göstermektedir (Çizelge 4 ve 5). Onur (2016) fide döneminde yapılan farklı dozlardaki (4.8 ve $9.6 \mathrm{~kJ} \mathrm{~m}^{-2}$ gün-1) UV-B 1 şın uygulaması sonucu Fortunas çeşidi marul fidelerinde 9.6 $\mathrm{kJ} \mathrm{m}^{-2}$ gün $^{-1}$ UV-B uygulamasının klorofil miktarını azaltığını belirlemiştir. Domates ve hıyar fidelerinde $16.2 \mathrm{~kJ} \mathrm{~m}^{-2}$ gün $^{-1}$ UV-B uygulamasının klorofil miktarındaki azaltıcı etkisi Onur (2016)'un araştırma sonuçlarıyla uyum göstermektedir.
$10.8 \mathrm{~kJ} \mathrm{~m}^{-2}$ gün $^{-1} \mathrm{UV}-\mathrm{B}$ 1şın uygulaması yapılan patlıcan fidelerinin yaprak rengine ait $C^{*}$ değeri 23.57 ile diğer gruplara göre daha düşük miktarda bulunurken, bu uygulamanın $C^{*}$ değerleri üzerine azaltıcı etki yaptığı saptanmıştır. 16.2 $\mathrm{kJ} \mathrm{m}^{-2}$ gün $^{-1}$ UV-B ışın uygulaması yapılan fideler ile kontrol grubu fidelerde $C^{*}$ değeri 25.10 olarak tespit edilmiştir. UV-B uygulamaları patlican fidelerinde yaprak renginin $L^{*}$ değerleri üzerine azaltıcı etki gösterirken, yüksek doz UV-B uygulamasının yaprak renginin $H^{o}$ açısı değerlerinin azalmasına neden olmuştur (Çizelge 6).

Onur (2016) marul fidelerinde farklı iki dozda yaptığ çalışmada $9.6 \mathrm{~kJ} \mathrm{~m}^{-2}$ gün$^{-1}$ UV-B uygulamasının $L^{*}$ renk değerini azaltıcı etki gösterdiğini, $4.8 \mathrm{~kJ} \mathrm{~m}^{-2}$ gün$^{-1} \mathrm{UV}-\mathrm{B}$ ışın uygulamasının istatiksel olarak bir değişikliğe neden olmadığını belirtmiştir. Araştırıcının yüksek doz $\left(9.6 \mathrm{~kJ} \mathrm{~m}^{-2}\right.$ gün$\left.^{-1}\right) \mathrm{UV}-\mathrm{B}$ uygulaması, çalışmamızda elde edilen sonuçları destekler niteliktedir.

\subsection{Toprak üstü aksamda ve kökte kuru madde miktarı ve protein miktarl}

Hıyar fidelerinde UV-B uygulama dozlarının kök kuru madde miktarını etkilemediği tespit edilirken, $10.8 \mathrm{~kJ} \mathrm{~m}^{-2}$ gün $^{-1}$ UV-B ışın uygulaması yapılan domates ve patlıcan fidelerinin kök kuru madde miktarı (\% 12.94-11.23) ile kontrol grubu domates ve patlıcan fidelerinin kök kuru madde miktarı (\% 13.48-11.62) arasında istatiksel olarak bir farklılık görülmemiştir. $16.2 \mathrm{~kJ} \mathrm{~m}^{-2}$ gün $^{-1}$ UV-B 1şın uygulamasının domates ve patlıcan fidelerinin kökte kuru madde miktarında (\% 15.90-14.35) artışa neden olduğu tespit edilmiştir (Çizelge 7, 8 ve 9$)$.

UV-B uygulama dozlarına paralel olarak hiyar fidelerinde toprak üstü aksamda kuru madde miktarlarında azalma meydana geldiği belirlenmiştir. UV-B uygulama dozu artıkça hıyar fidelerinin toprak üstü aksam protein içeriğinde artış meydana geldiği, patlıcan fideleri için bu artışın düşük doz UV-B uygulamasında görüldüğü belirlenmiştir (Çizelge 8 ve 9).

Çizelge 4. Farklı UV-B doz uygulamaların domates fidelerinde klorofil miktarı, $C^{*}, L^{*}$ ve $H^{\circ}$ açısı değerleri üzerine etkisi.

Table 4. The effects of different UV-B dose applications on chlorophyll content, $C^{*}, L^{*}$ ve $H^{\circ}$ angle values in tomato seedlings.

\begin{tabular}{lcccc}
\hline Uygulama Dozları & Klorofil miktarı (Spad) & $C^{*}$ & $L^{*}$ & $H^{\circ}$ \\
\hline Kontrol & $48.95 \mathrm{ab}$ & 23.11 & 43.05 & 126.89 \\
$10.8\left(\mathrm{~kJ} \mathrm{~m}^{-2}\right.$ gün $\left.^{-1}\right)$ & $49.34 \mathrm{a}$ & 21.45 & 42.51 & 126.49 \\
$16.2\left(\mathrm{~kJ} \mathrm{~m}^{-2}\right.$ gün $\left.^{-1}\right)$ & $47.77 \mathrm{~b}$ & 22.19 & 42.67 & 126.97 \\
\hline
\end{tabular}

$\mathrm{LSD} \%_{1}$ (klorofil) $=1.294, \mathrm{LSD} \% 1$ (chroma) $=$ Ö.D., LSD $\%_{1}$ ( L* renk değeri) $=$ Ö.D., LSD $\%_{1}$ (hue açı değeri) $=$ Ö.D.

Çizelge 5. Farklı UV-B doz uygulamaların hıyar fidelerinde klorofil miktarı, $C^{*}, L^{*}$ ve $H^{\circ}$ açısı değerleri üzerine etkisi.

Table 5. The effect of different UV-B dose applications on the amount of chlorophyll, $C^{*}, L^{*}$ ve $H^{\circ}$ angle values in cucumber seedlings.

\begin{tabular}{lccc}
\hline Uygulama Dozları & Klorofil miktarı (Spad) & $C^{*}$ & $L^{*}$ \\
\hline Kontrol & $51.09 \mathrm{~b}$ & 21.34 & 36.69 \\
$10.8\left(\mathrm{~kJ} \mathrm{~m}^{-2}\right.$ gün $\left.^{-1}\right)$ & $53.82 \mathrm{a}$ & 20.24 & 35.75 \\
$16.2\left(\mathrm{~kJ} \mathrm{~m}^{-2}\right.$ gün $\left.^{-1}\right)$ & $50.22 \mathrm{~b}$ & 21.58 & 37.15 \\
\hline
\end{tabular}

$\mathrm{LSD} \% 5$ (klorofil $)=2.247, \mathrm{LSD} \% 5$ (chroma $)=$ Ö.D., $\mathrm{LSD} \% 5\left(\mathrm{~L}^{*}\right.$ renk değeri $)=$ Ö.D., $\mathrm{LSD} \% 1$ (hue açı değeri $)=$ Ö.D.

Çizelge 6. Farklı UV-B doz uygulamaların patlıcan fidelerinde klorofil miktarı, $C^{*}, L^{*}$ ve $H^{\circ}$ açısı değerleri üzerine etkisi.

Table 6. The effects of different UV-B dose applications on chlorophyll content, $C^{*}, L^{*}$ ve $H^{\circ}$ angle values in eggplant seedlings.

\begin{tabular}{lcccc}
\hline \multicolumn{1}{c}{ Uygulama Dozları } & Klorofil miktarı (Spad) & $C^{*}$ & $L^{*}$ & $H^{\circ}$ \\
\hline Kontrol & 46.94 & $25.10 \mathrm{a}$ & $41.28 \mathrm{a}$ & $124.26 \mathrm{a}$ \\
$10.8\left(\mathrm{~kJ} \mathrm{~m}^{-2}\right.$ gün $\left.^{-1}\right)$ & 45.41 & $23.57 \mathrm{~b}$ & $40.36 \mathrm{~b}$ & $124.61 \mathrm{a}$ \\
$16.2\left(\mathrm{~kJ} \mathrm{~m}^{-2}\right.$ gün $\left.^{-1}\right)$ & 47.24 & $25.10 \mathrm{a}$ & $40.64 \mathrm{~b}$ & $123.32 \mathrm{~b}$ \\
\hline
\end{tabular}

$\mathrm{LSD} \%_{1}$ (klorofil $)=$ Ö.D., LSD $\% 5$ (chroma) $=1.242, \mathrm{LSD} \% 5(\mathrm{~L} *$ renk değeri $)=0.602, \mathrm{LSD} \% 5$ (hue aç 1 değeri $)=0.721$. 
Çizelge 7. Farklı UV-B doz uygulamaların domates fidelerinde toprak üstü aksam, kökte kuru madde ve protein miktarı üzerine olan etkisi.

Table 7. The effect of different UV-B dose applications on tomato seedlings, above ground, dry matter and protein amount on root.

\begin{tabular}{lccc}
\hline Uygulama Dozları & $\begin{array}{c}\text { Toprak üstü aksamda kuru } \\
\text { madde miktarı }(\%)\end{array}$ & $\begin{array}{c}\text { Toprak üstü aksamda } \\
\text { protein miktarı }(\%)\end{array}$ & $\begin{array}{c}\text { Kökte kuru madde miktarı } \\
(\%)\end{array}$ \\
\hline Kontrol & 8.88 & 14.70 & $13.48 \mathrm{~b}$ \\
$10.8\left(\mathrm{~kJ} \mathrm{~m}^{-2}\right.$ gün $\left.^{-1}\right)$ & 8.66 & 14.53 & $12.94 \mathrm{~b}$ \\
$16.2\left(\mathrm{~kJ} \mathrm{~m}^{-2}\right.$ gün $\left.^{-1}\right)$ & 8.72 & 16.82 & $15.90 \mathrm{a}$ \\
\hline
\end{tabular}

LSD $\% 5$ (toprak üstü kuru madde $)=$ Ö.D., LSD $\% 5$ (toprak üstü protein $)=$ Ö.D., LSD $\% 5$ (kök kuru madde $)=1.582$, LSD $\% 5($ kök protein $)=$ Ö.D.

Çizelge 8. Farklı UV-B doz uygulamaların hıyar fidelerinde toprak üstü aksam, kökte kuru madde ve protein miktarı üzerine olan etkisi. Table 8. The effect of different UV-B dose applications on cucumber seedlings, above ground, dry matter and protein amount on root.

\begin{tabular}{lccc}
\hline Uygulama Dozları & $\begin{array}{c}\text { Toprak üstü aksamda kuru } \\
\text { madde miktarı }(\%)\end{array}$ & $\begin{array}{c}\text { Toprak üstü aksamda } \\
\text { protein miktarı }(\%)\end{array}$ & $\begin{array}{c}\text { Kökte kuru madde miktarı } \\
(\%)\end{array}$ \\
\hline Kontrol & $8.78 \mathrm{a}$ & $19.04 \mathrm{~b}$ & $\begin{array}{c}\text { Kökte protein miktarı } \\
(\%)\end{array}$ \\
$10.8\left(\mathrm{~kJ} \mathrm{~m}^{-2}\right.$ gün $\left.^{-1}\right)$ & $8.15 \mathrm{ab}$ & $19.77 \mathrm{ab}$ & 12.98 \\
$16.2\left(\mathrm{~kJ} \mathrm{~m}^{-2}\right.$ gün $\left.^{-1}\right)$ & $7.66 \mathrm{~b}$ & $21.82 \mathrm{a}$ & 12.00 \\
\hline
\end{tabular}

LSD $\% 5$ (toprak üstü kuru madde $)=0.802$, LSD $\% 5$ (toprak üstü protein $)=2.056$, LSD $\% 1$ (kök kuru madde)= Ö.D., LSD \% 5 (kök protein) $=$ Ö.D.

Çizelge 9. Farklı UV-B doz uygulamaların patlıcan fidelerinde toprak üstü aksam, kökte kuru madde ve protein miktarı üzerine olan etkisi.

Table 9. The effect of different UV-B dose applications on the amount of dry matter and protein in the overgrowth, root in eggplant seedlings.

\begin{tabular}{lccc}
\hline Uygulama Dozları & $\begin{array}{c}\text { Toprak üstü aksamda kuru } \\
\text { madde miktarı }(\%)\end{array}$ & $\begin{array}{c}\text { Toprak üstü aksamda } \\
\text { protein miktarı }(\%)\end{array}$ & $\begin{array}{c}\text { Kökte kuru madde miktarı } \\
(\%)\end{array}$ \\
\hline Kontrol & 11.59 & $12.34 \mathrm{~b}$ & $\begin{array}{c}\text { Kökte protein miktarı } \\
(\%)\end{array}$ \\
$10.8\left(\mathrm{~kJ} \mathrm{~m}^{-2}\right.$ gün $\left.^{-1}\right)$ & 13.06 & $20.31 \mathrm{a}$ & $11.62 \mathrm{~b}$ \\
$16.2\left(\mathrm{~kJ} \mathrm{~m}^{-2}\right.$ gün $\left.^{-1}\right)$ & 11.47 & $11.29 \mathrm{~b}$ & $1.23 \mathrm{~b}$ \\
\hline
\end{tabular}

LSD \% 1 (toprak üstü kuru madde $)=$ Ö.D., LSD \% 1 (toprak üstü protein $)=2.384$, LSD $\% 1$ (kök kuru madde $)=1.993$, LSD $\% 1($ kök protein $)=$ Ö.D.

\section{Sonuç}

Fidelerde pişkinleşmeyi sağlamak için stres faktörleri ile ilgili çalışmalar yapılmaktadır. Bununla birlikte bir stres faktörü olan UV-B ışın uygulamalarının fide gelişimi ve kalitesi üzerine etkileri önem taşımaktadır.

Domates ve hıyar fidelerinde UV-B ışın uygulamalarının kök gelişimini baskıladığı, domates fidelerinde kök boğazı çapında artışa neden olurken hıyar ve patlıcan fidelerinde kök boğazı çapında azalmaya sebep olduğu belirlenmiştir. 16.2 $\mathrm{kJ} \mathrm{m}^{-2}$ gün $^{-1}$ UV-B uygulamas1 domates ve patlican fide köklerinde kuru madde birikimini artırıcı etki göstermiştir. $\mathrm{Bu}$ veriler doğrultusunda $16.2 \mathrm{~kJ} \mathrm{~m}^{-2}$ gün $^{-1}$ UV-B uygulamasının domates fidelerinde kök kuru madde miktarı ve kök boğazı çapında artışa neden olmasından dolayı fide pişkinleşmesinde olumlu rol oynayabileceği düşünülmektedir.

Yaprak sayısı hıyar fidelerinde $16.2 \mathrm{~kJ} \mathrm{~m}^{-2}$ gün $^{-1}$ uygulamasında artarken yaprak alanı bu uygulama ile azalmıştır. Domates fidelerinde ise $10.8 \mathrm{~kJ} \mathrm{~m}^{-2}$ gün $^{-1}$ uygulamasında yaprak sayısı azalırken $16.2 \mathrm{~kJ} \mathrm{~m}^{-2}$ gün $^{-1}$ uygulamasında yaprak sayısında artış meydana gelmiştir. UV-B uygulaması yapılan patlıcan fidelerinde yaprak alanında azalma saptanmıştır.

Patlican fidelerinde yaprak renginin $C^{*}$ değerleri 10.8 $\mathrm{kJ} \mathrm{m}^{-2}$ gün $^{-1}$ uygulamasında azalırken, $L^{*}$ değerleri her iki dozda da düşüş göstermiştir. $H^{o}$ açısı değerleri ise $16.2 \mathrm{~kJ} \mathrm{~m}^{-2}$ gün$^{-1}$ uygulamasında azalmıştır. UV-B uygulaması patlıcan fide yapraklarının mat ve donuk bir görünüm kazanmasına neden olmuştur.

Dünyamıza ulaşan UV-B ışınlarının bitkiler ve canlılar üzerine olan etkileri son y1llarda yapılan araştırmalarla önem kazanmıştır. Çalışmanın fide döneminde yapılacak uygulamaların fide yetiştiriciliğinde veya hazır fide sektöründe adaptasyon, patojenlere dayanıklılık ve pişkinleştirme işlemine katkı sağlaması açısından önemli sonuçlar içerebileceği düşünülmektedir.

\section{Teşekkür}

$\mathrm{Bu}$ araştırma yüksek lisans tez çalışmasındaki verilerin bir kısmından oluşmaktadır. Desteklerinden dolayı Akdeniz Üniversitesine teşekkür ederiz.

\section{Kaynaklar}

Anderson JG, Toohey DW, Brune WH (1991) Free radicals within the Antarctic vortex: The role of CFCs in Antarctic Ozone Loss. Science 251: 39-46.

AOAC (1992) Official Method 992.23. Crude Protein in Cereal Grains and Oilseeds. Washington DC, USA.

Del Corso G, Lercari B (1997) Use of UV radiation for control of height and conditioning of tomato transplants (Lycopersicon esculentum Mill.). Scientia Horticulturae 71: 27-34.

Fedina I, Hidema J, Velitchkova M, Georgieva K, Nedeva D (2010) UV-B induced stress responses in three rice cultivars, Biologia Plantarum 54: 571-574.

McFarland M, Kaye J (1992) Chlorofluorocarbons and ozone. Photochemistry and Photobiology, 55: 911-929.

Onur A (2016) Marullarda Fide Döneminde Yapılan UV-B Işın Uygulamalarının Bitki Gelişimi, Ürün Verimi ve Kalitesi Üzerine Etkileri. Yüksek Lisans Tezi, Akdeniz Üniversitesi Fen Bilimleri Enstitüsü, Antalya.

Shaukat SS, Farooq MA, Siddiqui MF, Zaidi S (2013) Effect of enhanced UV-B radiation on germination, seedling growth and biochemical responses of Vigna mungo (1.) hepper. Pakistan Journal of Botany 45(3): 779-785.

TS1129/ISO 1026 (1998) Meyve ve sebze ürünleri düşük basınç altında kurutma ile kurumadde ve azeotropik distilasyon metodu ile su muhtevasının tayini. Türk Standartları Enstitüsü, Yayın No: 1129/ISO 1026, Ankara. 
Uslu A, Özgür M (2002) Hıyar Fidesi Yetiștiriciliğinde Boylanmanın Kontrolü Üzerine Bazı Büyümeyi Düzenleyici Maddelerin Etkisi. VI. Sebze Tarımı Sempozyumu Bildiriler Kitabı, Uludağ Üniversitesi Basımevi, Bursa, s. 49-56.

Yuan L, Ming Y, Xunling W (1998) Effects of enhanced ultraviolet-B radiation on crop structure, growth and yield components of spring wheat under field conditions. Field Crops Research, 57(3): 253263.
Zlatev ZS, Lidon FC, Kaimakanova M (2012) Plant physiological responses to UV-B radiation. Emirates Journal of Food and Agriculture 6: 481-501. 